\title{
An Information Systems Master Programme in Romania. Some Commonalities and Specificities
}

\author{
Marin FOTACHE, Florin DUMITRIU, Valerică GREAVU-ȘERBAN \\ Alexandru Ioan Cuza University of Iaşi \\ fotache@uaic.ro,fdumi@uaic.ro,valy.greavu@feaa.uaic.ro
}

This paper presents some preliminary results of a survey conducted in 2013 and 2015 for the graduates of Information Systems (IS) master programme at Al.I.Cuza University of Iasi. The survey main objectives were to gather information about graduates employability, to identify the required skills on the IT market, to find out the graduates opinion about the programme (including curricula, syllabi, internship, infrastructure, teaching staff), and program strengths and weaknesses and re-align curricula to the industry demand. A brief description of main IS career tracks was provided according to ACM/AIS curricula guidelines. Enrollment for both undergraduate and master IS programmes were compared to international trends. Some other assumptions which were checked relate to: the type of employers and customers of the IT projects the graduates work for, the moment of getting the first job, the structure IT vs. non-IT and managerial vs. non-managerial (also overall and by genre) positions/jobs of the graduates. The IT functional (sub)areas of graduates positions were discussed in relation to the current state of Romanian IT market which is massively dependent on off shoring.

Keywords: Information Systems Curricula, Graduates Survey, IS Employability, IS Programmes - Industry Alignment

\section{1}

\section{Introduction}

As academic discipline and research topic, Information Systems (IS) has followed a convoluted trajectory. It's never ending identity crisis [1], [2] combined with a steep decline in enrolments in developed countries since the dot.com bust of 2001-2003, especially in US and UK programmes [3], [4], [5], rose questions about its future. Some MIS programs in the United States have completely shut down because of low enrolment [5], [6]. The main reason given in the literature for this decline is the off shoring of IT jobs [7], [6].

Amidst funeral moods, Romanian (and other low-wage countries) IS programmes have thrived at both undergraduate and graduate levels [3]. Romania's increasing attractiveness for IT outsourcing (lower wages, technical skills, proficiency in foreign languages) created a big appetite for IT professionals and consequently IS enrolment has constantly risen. National and European statistical and academic studies revealed that from the beginning of the economic crisis (2008 in Romania) until the end of 2014, the number of jobs in the IT sector has doubled in Roma- nia, and the demand continues to rise exponentially [8], [9], [10].

One thing that is clear is that the globalization of software is here to stay, and its manifestation as IT services off shoring is a disruptive force that has a long-term effect on the domestic IT work force. This phenomenon brings many challenges to adapting the IT/IS education system. It has not only to prepare growing numbers of people to work in IT industry, but also to cope with different and changing occupations, each with its own skills and knowledge requirements. IT work can be thought of as consisting of a spectrum from the more routine (e.g. system maintenance and support, basic programming, system testing) through the more advanced (e.g. requirements management or system architecture development) to the advanced strategic (development of approaches that utilize IT to provide organisation with a competitive advantage), each of them asking for different mixture of technical, business, and soft skills. The literature review doesn't provide a clear picture about IT jobs and skills that are being currently offshored or might be offshored in the future. Some authors state that all IT 
jobs/skills might be offshored arguing that IT skills tend to become new comodity [11], [12], while others try to prove that not all of its could be offshored and that the vulnerability to offshoring depends on some features of IT jobs/skills, such as the need for interpersonal interaction and face-to-face contact, the physical presence of workers in a fixed location and leading to a competitive advantage [13], [14]. Moreover, data on current and future trends of off shoring leave much to be desired [15]. All these conditions make difficult to describe the current state and the prediction about global and domestic IT work force market.

As technologies change quickly, so the industry requirements, IS programmes must adapt their curricula based on similar programmes curricula, including model curriculum guidelines published by Association for Information Systems [3], listening to the industry needs (involving industry representatives), and getting feedback from graduates.

This paper presents some results of a survey targeting Business Information Systems master graduates at Al. I. Cuza University of Iasi (UAIC). The aim of our study was not only the programme evaluation but also to give an outlook on Romanian IT workforce.

Technical solution for analysis was developed using Microsoft SharePoint Server platform for data collection and R/R Studio language/platform for data analysis.

\section{Information Systems Undergraduate and Graduate Programmes Curricula}

As technical and business topics could be mixed in various proportions, diversification of IS programmes manifests not only among universities from different countries, but also within the same country [3]. At UAIC both undergraduate and graduate Information Systems programmes curricula were developed ACM/AIS guidelines [3], [16], [17]. Figure 1 shows the main courses proposed in IS2010 undergraduate curriculum [16] model and their relation to the career tracks of the IS graduates.

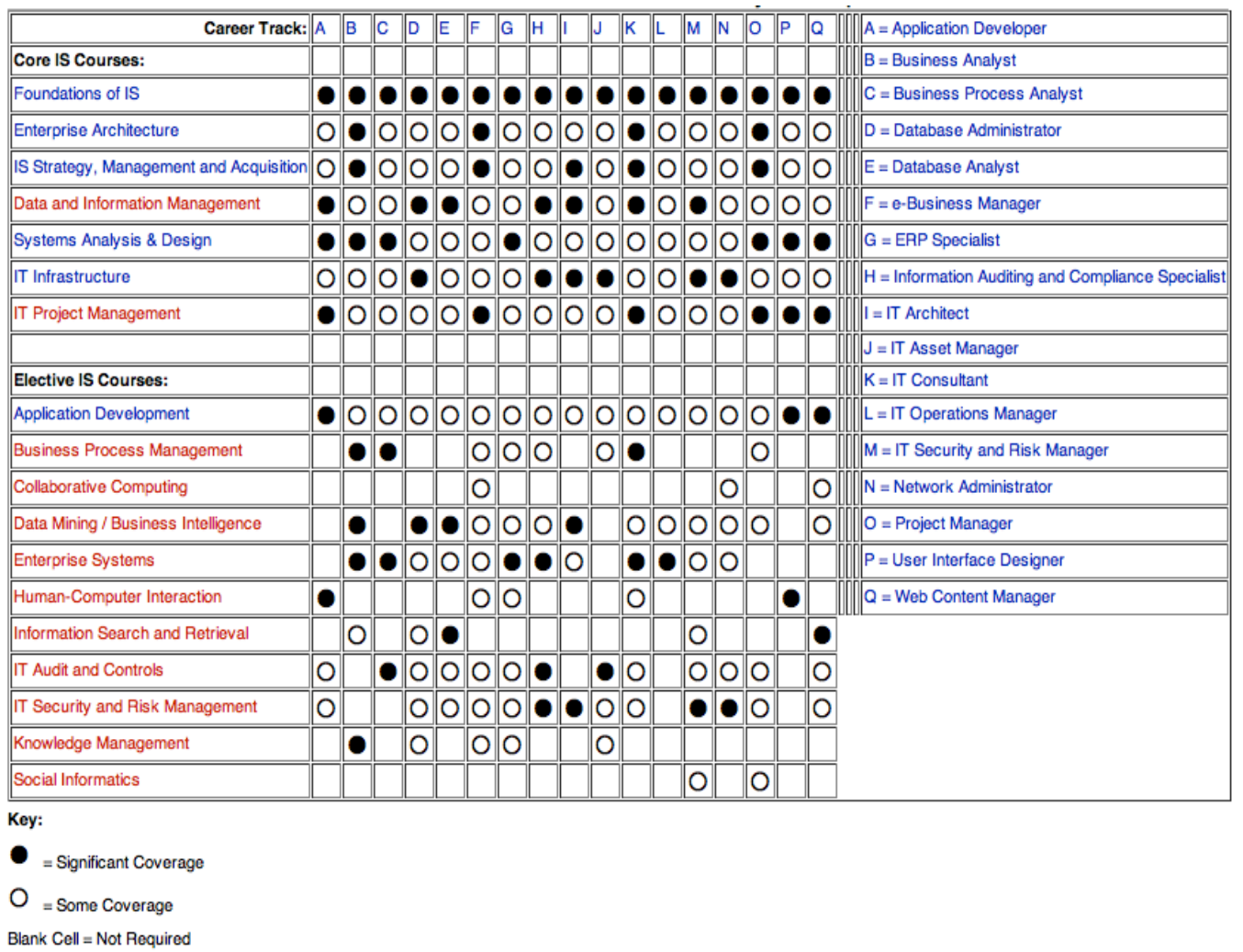

Fig. 1. Structure of ACM/AIS IS2010 undergraduate curriculum [16]

At master level, the most recent recommendation is MSIS2006 [17]. The next curricu- lum model for IS graduate programmes is expected within a year or two. MSIS2006 
nominated 24 possible career tracks (such as: Academia; Knowledge Management; Computer Forensics; Managing the IS Function; Consulting; Data Management and Warehousing; Mobile Computing; Database and Multi-tiered Systems; Decision Making; Project Management; Security; Systems Analysis \& Design; Enterprise Resources Planning; Telecommunications) each with suggested courses. Since 1997 (undergraduate) and 2007 (master), IS programmes at UAIC have been properly aligned to ACM/AIS recommendations. However the guidelines suitability for Romanian IS programs is debatable. Romanian IT market is massively influenced by globalization, being a recipient of off shored IT services. Although adopted around the world, the model curricula have been designed primarily for degree programs in the United States [15], which is acting as the most important source in IT off shoring. We would argue that, at the moment, the professional associations/societies should develop not only one-fits-all curricula, but at least two, one for high-wage countries which act as source in the IT global market and one for low-wage countries as a destination/recipient of off shored IT services.

\section{Graduates Survey Brief Description. Technical Platforms}

Graduates survey was designed in 2013 and made available for graduates from September

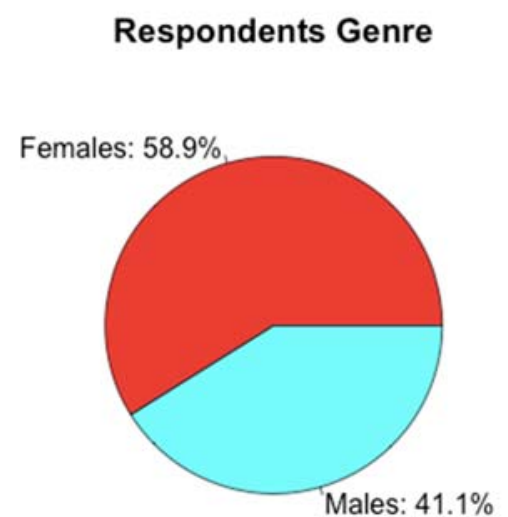

Fig. 2. Respondents' genre (left) and enrolment year (right)

Analysing the number of answers per admission year (figure 2, right) one can notice some discrepancies between 2009/2010 and $2011 / 2012$. Based on the number of enrolled

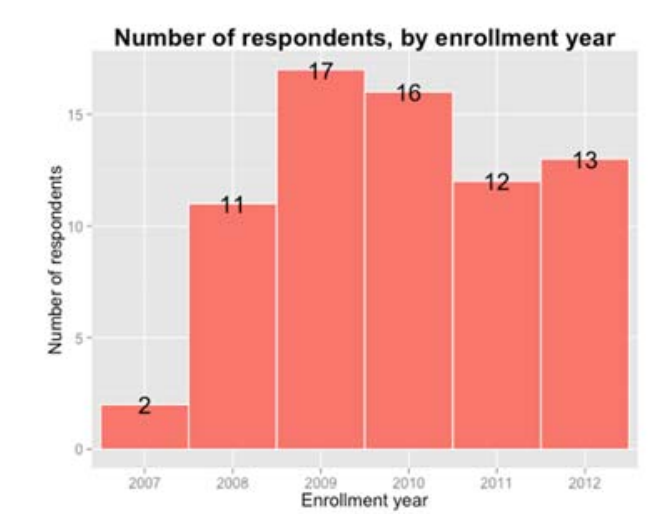

to December 2013 and from January to March 2015. Some of the sections of questionnaire are: Personal details (e.g. age, gender); Graduation path for both bachelor and master levels; Carrier path (year of first employment, company profile, location and stakeholders, income level; Free/open messages (for teachers, colleagues, future students, five positive and five negative features of the programme); Level of satisfaction about teaching staff and activities, different areas of interest (programming, modelling, databases, etc.) research opportunities and administrative components of master degree, all using a Likert scale from 1 to 5 .

The questionnaire was distributed through social networks (mainly on Facebook, where graduates have group pages organized by enrolment year). There were 84 answers, but only 74 were kept as the 10 of them were flawed (seven respondents did not respond to any questions, and three seem to be still students and not graduates) etc.

Proportion of the respondents' genre follows the proportion of students' genre for BIS (figure 2 , left). $58.9 \%$ of respondents are females and only $41.1 \%$ males. The proportion of graduates for our master programme is $57.01 \%$ for females and $42.99 \%$ for males.

This contradicts a much-debated anxiety - the scarcity of women in computing.

students and the "fresh memory" factor, we expected the number of 2011/2012 respondents to be bigger than for $2009 / 2010$. The figures indicate the opposite. Somehow iron- 
ically, this psychological factor of memory freshness might be part of the explanation.

As students BIS graduates had extensively used (Microsoft) SharePoint technologies. So, we chose it as platform for the questionnaire instead of an equivalent free solution. SharePoint assures a better control over the respondents (as former UAIC students). Free Internet surveying tools allowed anonymous answers but malicious people might fill in multiple malformed answers and alter the results. Even if the free tools surveys could be protected by the uniqueness of an IP address, it is largely acknowledged that any person can access many devices connected to the Internet, or can use proxy servers to access and respond multiple times to a survey.

For data visualization and analysis we chose an increasingly popular open-source plat- form, $\mathrm{R} / \mathrm{RStudio}$. $\mathrm{R}$ is the most dynamic data language [18], [19]. Main $\mathrm{R}$ packages used in this analysis are: $v c d$ [20], stringr [21], [22], reshape [23], plyr [24], dplyr, ggplot2 [25], and likert [26].

\section{Graduates Employability}

Figure 3 (left) shows that graduates employability is quite satisfactory $(95 \%)$. $85 \%$ of graduates had been hired before master completion. First and second year of study are most frequent moments of getting the first job. This data is consistent with a recent IS department internal survey targeting current second year BIS master students. Out of 66 current (in 2014-2015 academic year) second year students, 57 (86\%) declared they are already hired.
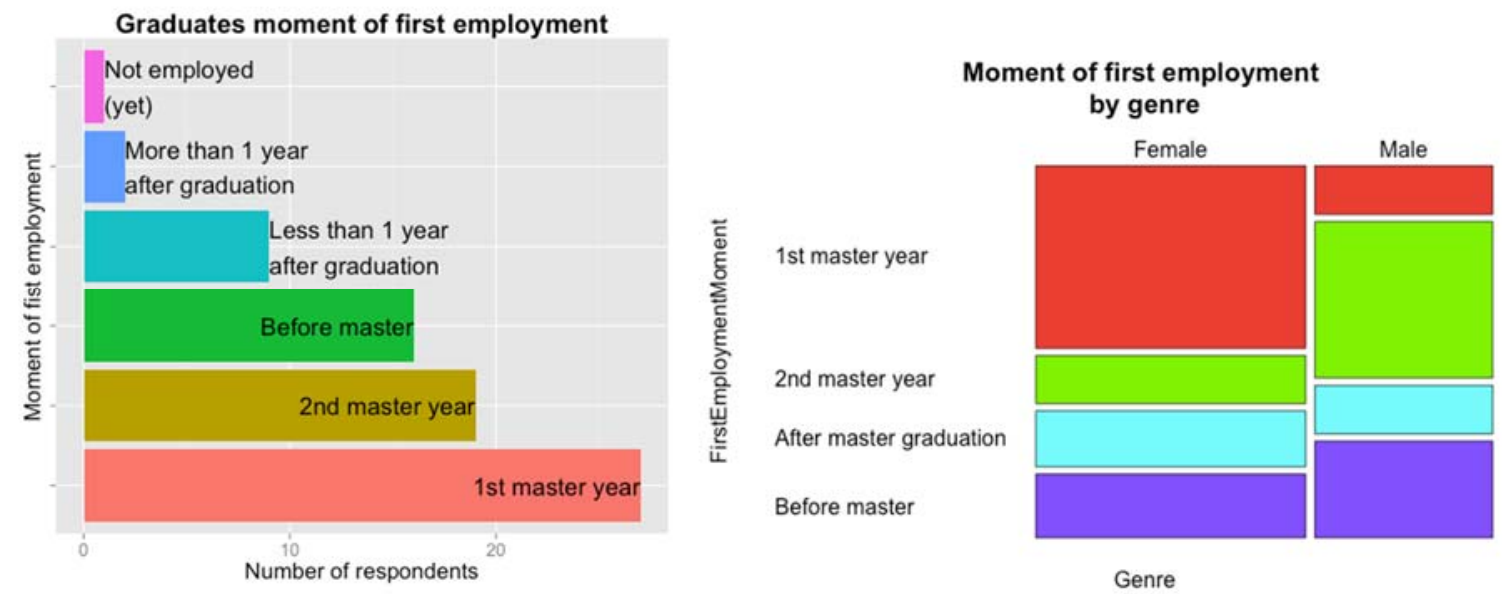

Fig. 3. Respondents' first job moment - overall (left) and grouped by genre (right)

This is good news for the programme and reflect not only the increasing demand for IS/IT professionals, but also suggests a proper alignment of IS programme to the industry needs. Later years have witnessed a growing number of applications for both undergraduate and graduate IS programmes. The number of applicants for the undergraduate/graduate programme has been increasing every year since 2010: 132/79 applicants in 2010, $147 / 88$ in $2011,169 / 96$ in $2012,214 / 101$ in 2013 and 242/78 in 2014. The trend for master degree was similar to that of the undergraduate programme, except for 2014 when the number decreased because of the re- striction imposed by ARACIS (Romanian authority for quality assessment in higher education) in 2011 for the undergraduate programme. The restriction was mainly bureaucratic, and limited the undergraduate number of positions to 100 .

The mosaic plot in the right side of Figure 3 shows a difference between male and female respondents in terms of the moment of the first employment. The proportions of males and females first hired before and after the master are similar. But female students seem to find a job mainly in the first year of the master, whereas the boys get hired mainly on the second year of the master. Further we 
tested if the observed difference is statistically significant and stated the following null hypothesis: H0: The moment of first employment and the respondents' genre are independent (there are no differences between male and female graduates concerning the moment of first employment). The alternative hypothesis is Ha: The moment of first employment is related to the respondents' genre (there are differences between male and female graduates concerning the moment of first employment). Function chisq.test (base $\mathrm{R})$ returned chi-squared $\chi 2(\mathrm{df}=3)=14.3289$,

Is the employer an IT or a non-IT company?

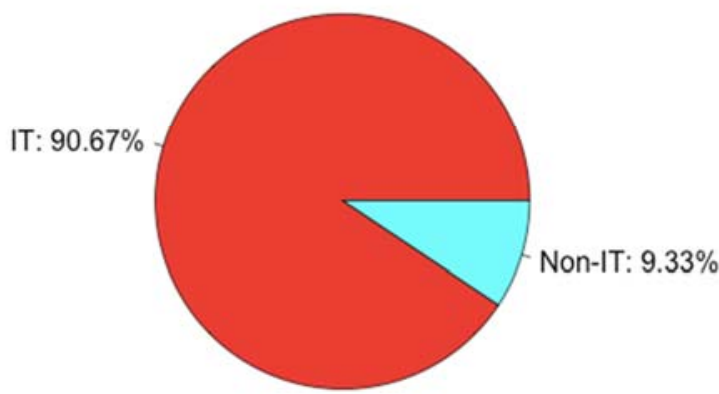

Fig. 4. Jobs in IT vs. non-IT industry (left) and grouped by genre (right) $\mathrm{p}$-value $=0.0025$. Similarly, function fisher.test (which computes a Fisher's Exact Test) returned a p-value $=0.0018$. Based on the two p-values $\mathrm{H} 0$ can be rejected, so our sample suggest there are significant statistical differences between male and female graduates in terms of the moment of first employment.

As expected, most of the respondents work in IT industry $(90.54 \%)$ - Figure 4, left. We were interested if a particular genre tends to work in IT relative to the other genre - see Figure 4, right.

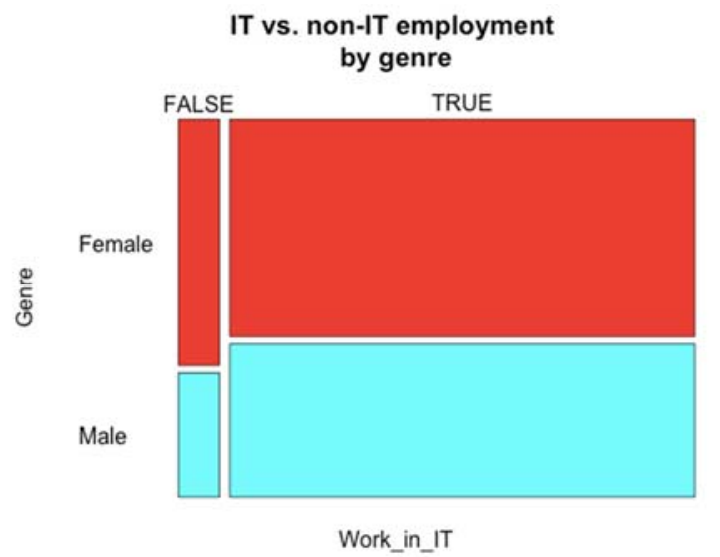

Graphically there seems to be no major differences among genres in terms of the "ITness" of graduates' jobs. In order to confirm the observation we test statistically the null hypothesis H0: Working in IT and genre are independent. Both chi-square test and Fisher's exact test results fail to reject $\mathrm{HO}$ (pvalue $=1)$. Consequently, there is no enough statistical evidence to claim that male graduates tend to work more in IT whereas the female graduates do not, or vice-versa.

Another subject of interest related to graduates employability was the profile of the employers. As less than $10 \%$ of the graduates work in non-IT industries, the analysis of employers' activity areas would be less relevant. Instead we focused on the ownership of the employers. We wanted to check a generally accepted statement that the main employers of Romanian computing graduated are foreign companies or Romanian compa- nies that outsource various projects and/or processes for western companies.

The bar chart in Figure 5 shows the frequency of employers grouped by ownership type. Based on our sample, we tried to estimate the proportion of international employers. We stated the following null hypothesis: $\mathrm{HO}$ : the proportion of internationally based employers is smaller than or equal to the proportion of (mostly) Romanian employers. Alternative hypothesis was Ha: the proportion of (mostly) international employers is greater than the proportion of (mostly) Romanian employers. Function prop.test returned chi-squared $\chi 2(1, \mathrm{~N}=70)=8.929, \mathrm{p}$-value $=0.0014$. Estimated proportion was 0.686 and the $95 \% \mathrm{CI}$ for proportion of internationally based employers was $[0.582,1]$. There seems to be enough statistical evidence to reject the null hypothesis and to support the idea that the main employers of IS graduates are international (mostly European) companies. 


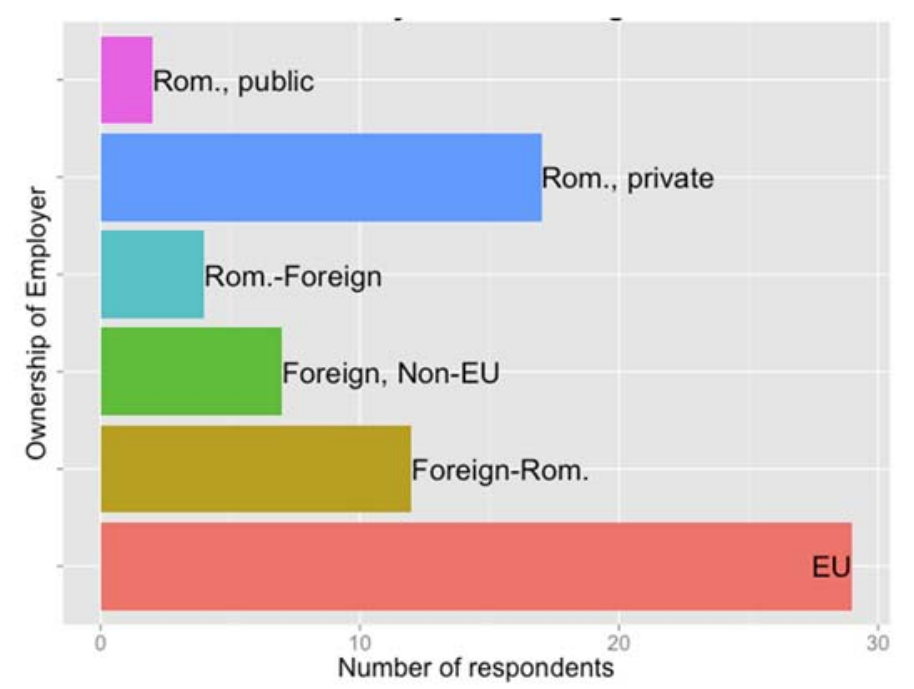

Fig. 5. Employers' ownership

Since there are Romanian or mixed ownership companies that work primarily for international customers, respondents were asked to specify the type of customers of IT projects they work for.

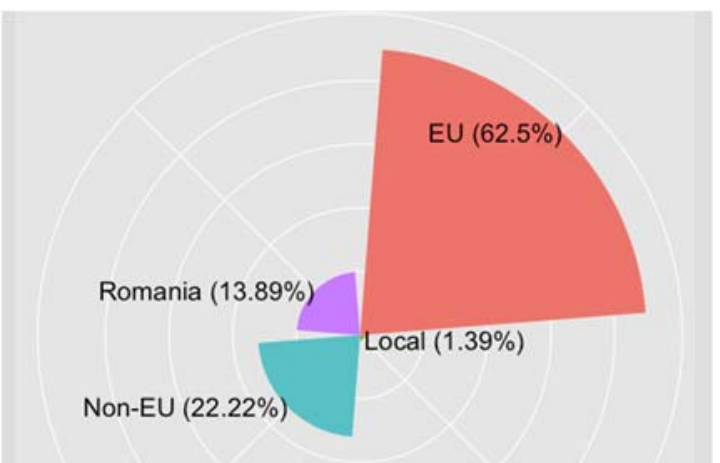

Fig. 6. Customer location of the IT projects graduates work for

The circular chart in Figure 6 suggest that the main customers of IT projects the IS graduates work for are internationally based, and Romania is on the IT outsourcing European map.

\section{Main Job Areas}

Graduates jobs areas/fields are very important in calibrating the curriculum. As presented in Figure 7 most frequent of the jobs are technical, software development related. This is natural since graduates get managerial positions (project/team managers) only after a few years of experience and proof of their competencies in working within and/or assembling a team. Jobs are concentrated on five main areas - Quality assurance, Programming, Databases and IS analysis and design - which covers $85 \%$ of total answers.
Figure 6 supported the claim of increasing number of western outsourced IT projects in Romania. Moreover, from Figure 7 one can infer that the outsourced projects target the final stages of software development (i.e. programming, testing and deployment) and the first stages (requirements analysis, design) remain mostly at headquarters. Our findings seem to confirm that the companies in high-wage countries are considering project management skills and business domain knowledge as critical and retain them inhouse, while they tend to offshore technical skills that are seen as commodity (Carr, 2003). Companies in developed countries are seeking client-facing capabilities, project management and business domain knowledge over technical capabilities (Bul- 
len, Abraham, Gallagher, Simon, \& Zwieg, 2009).

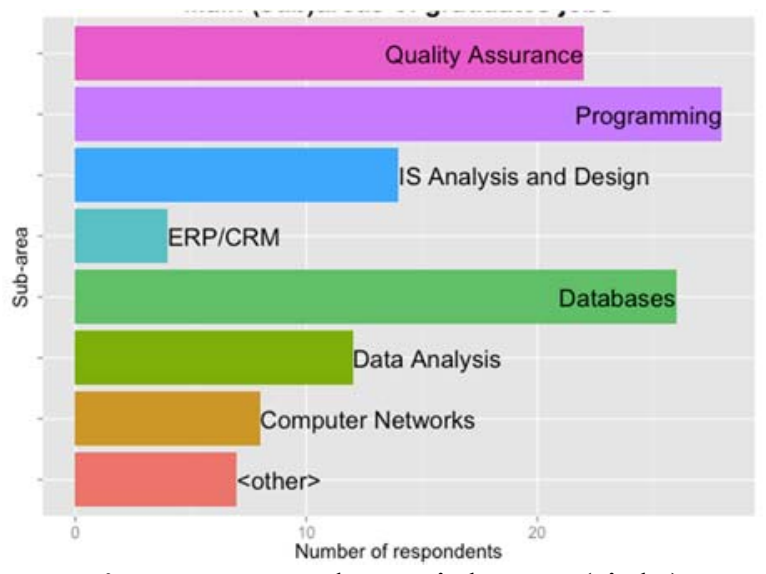

Fig. 7. Respondents' job area (right)

Also Figure 7 shows a specific trait for what employers demand from IS graduates. Generally Western IS programmes focus on business/managerial issues [28], [29], whereas most of the Romanian IS graduates must cope with technically oriented jobs, i.e. programming, databases, and computer networks. These results are also consistent with similar studies from Eastern Europe and Asia [30], [31]. Before 2010 a larger proportion of graduates was hired in ERP/CRM projects as consultants, implementers and mostly business related activities. As the crisis hit most of the ERP projects, demand for business related jobs has shrunk. Fortunately ERP scarcity was outpaced by more technically outsourced projects [32]. Recent changes in the IT jobs urges recalibrating the proportion of business and technical courses in IS curricula.

We were also interested in testing an old cliché in computing industry: women aren't so technically oriented than males. The mosaic plot in Figure 8 shows no huge gaps between males and females in terms of job/position functional area.

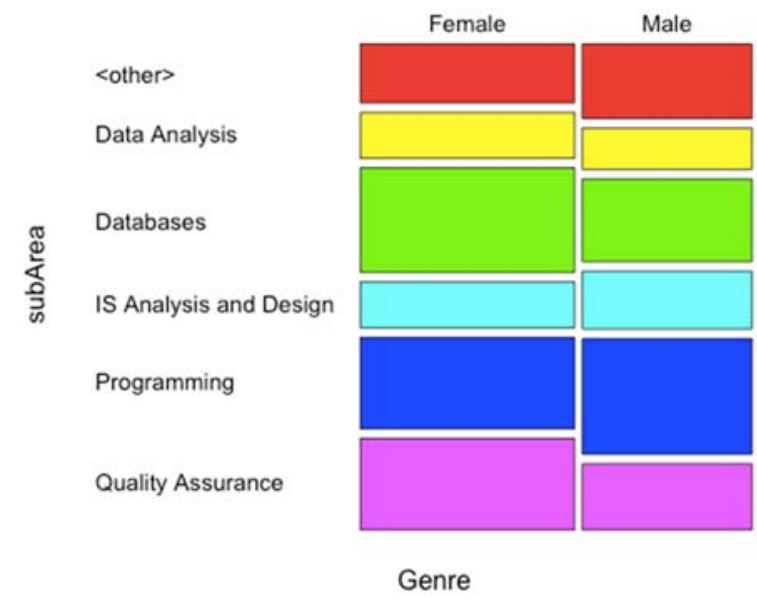

Fig. 8. Graduate positions, grouped by job area and genre

This observation can be enforced statistically using the classical chi-square and Fisher's tests for categorical variables. The tested null hypothesis is H0: subArea and Genre are independent (there are no statistical significant differences between female and male gradu- ates in terms of IT functional area of their current positions). Both functions (chisq.test and fisher.test) returned a p-value greater than 0.88 . Consequently there is no enough statistical evidence to reject the hypothesis 
that both male and female graduates target positions in similar IT functional (sub) areas. Our finding is slightly contrasting with the general opinion that women choose a technical path infrequently but confirms the opinion that this might not be true for women from Asia or Eastern Europe [5].

Because many IT companies are "new on market" we estimate that more of the IS

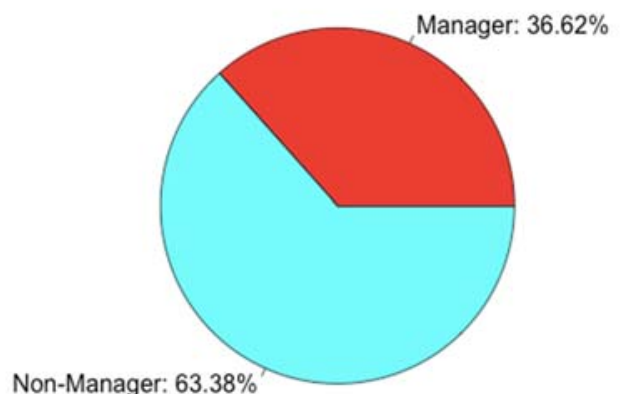

graduates are achieving in few years an IT managerial position: team leader, project manager, etc. Even the previous ideas statute that managerial position are coming from source countries of outsourcing, local leadership is very important for the productivity of every company.

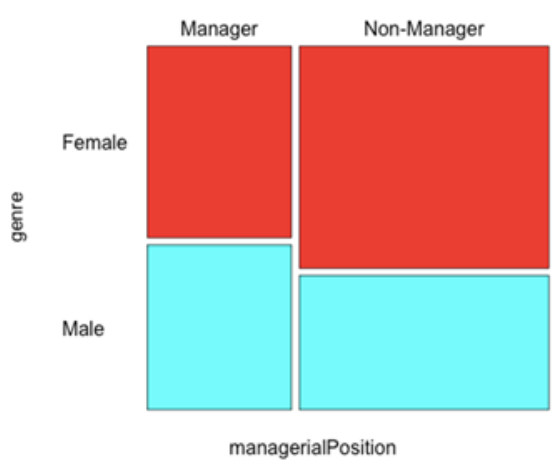

Fig. 9. Managerial positions - overall (left) and grouped by genre (right)

The pie chart in Figure 9 (left) shows the proportion of IS graduates who are filling managerial positions in the company they were hired. Based on our data, we tried to estimate the proportion of managerial positions from gender perspective. We stated the following null hypothesis $\mathrm{H} 0$ : managerial positions and genre are independent. Function prop.test returned chi-squared p-value $=$ 0.6591 and Fisher test returned $p$-value $=$ 0.6172 . The tests fail to reject the null hypothesis, so we are biased to conclude that there is no genre gap (or discrimination) in acceding to a managerial position in Romanian IT industry.

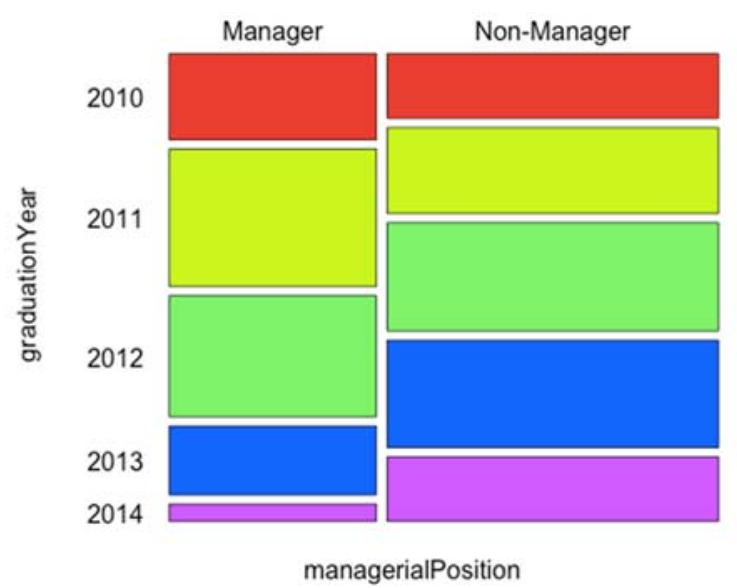

Fig. 10. Managerial positions vs. graduation year

Next we were interested in finding enough evidence for claiming that getting a managerial position was easier for some particular graduation years. As seen in Figure 10, the number of managerial position seems to be higher for graduates for 2011 and 2012.
Based on experience in companies and mechanisms for advancement position, we tested the following null hypothesis $\mathrm{HO}$ : managerial positions and graduation year are dependent. Function prop.test returned chi-squared $p$-value $=0.4798$ and Fisher test 
returned $p$-value $=0.5043$. So based on our sample the H0 cannot be rejected and we conclude that there is no statistical evidence to claim that getting a managerial position was particularly easy in some graduation years.

\section{Programme Evaluation by the Gradu- ates}

To evaluate the master programme, graduates were asked to assess, using a five-level scale (very poor, poor, average/neutral, good, and very good), the following items:
- the programme (at general level),

- courses (utility for their careers, teaching, link to practice, research content),

- professors (teaching, availability, attitude towards students),

- infrastructure (labs, classrooms, public spaces),

- administrative staff performance and attitude towards students/graduates,

- the Internship, etc.

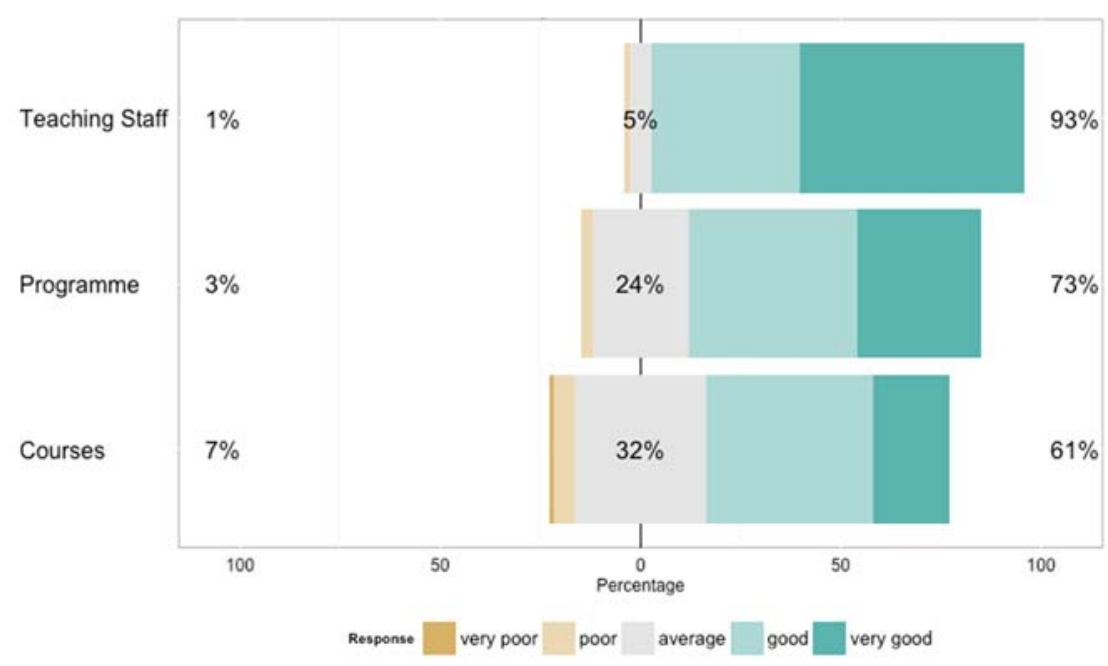

Fig. 11. Evaluation of teaching staff, programme and courses

Figures 11 and 12 show high score for teaching staff, master programme and courses $(94 \%, 69 \%$ and $59 \%)$. Adding half of the average level assessments, the positive percentages reach $96 \%, 84 \%$ and $77 \%$. This suggests proper teaching skills, availability and proper attitude towards students, a very positive image about programme and positive opinion about courses.

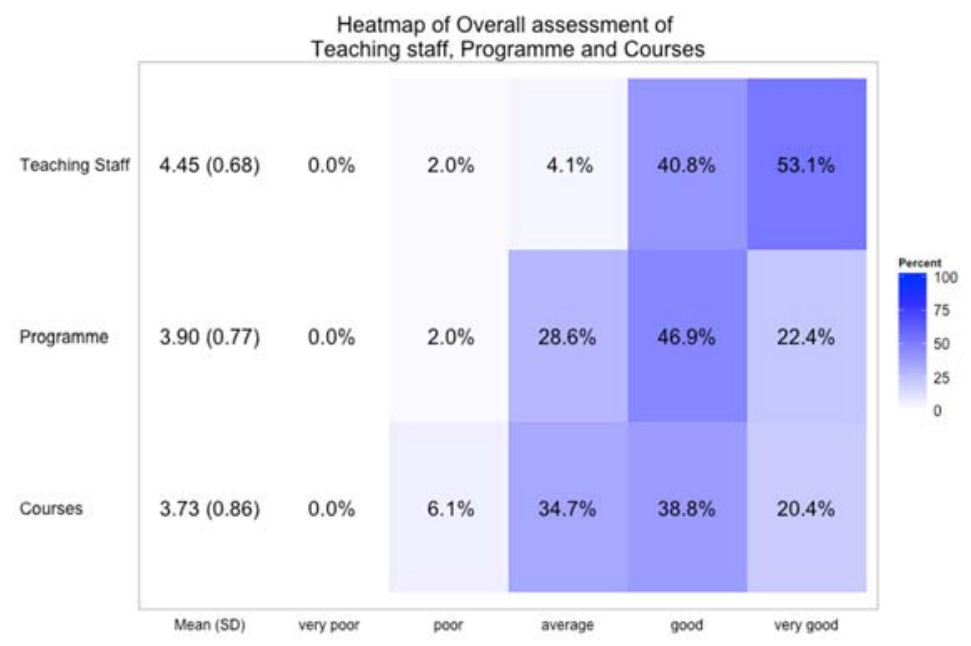

Fig. 12. Evaluation of teaching staff, programme and courses as a heatmap 
These findings are also enforced by the mean values $-4.45,3.90$ and 3.73 - out of a maximum of 5 , and the relative low standard deviations (Figure 12).

Overall programme assessment ranges between teaching stuff and courses assessments and that the latter has a smaller contribution on the programme score. Therefore, we think it will be necessary to conduct a more detailed survey in order to find out which courses have to be updated or even which revisions on IS curricula are requested and consequently get the proper alignment of the programme to the industry needs. Also, the new study has to validate the hypothesis of increasing need on technical courses and diminishing business-oriented ones.

\section{Limits, Discussions and Conclusions}

This article analyses curriculum issues and employability of Business Information Systems Master Programme from the perspectives of alumni, based on their experience during the studies and how this programme influenced their careers. Privacy and malevolent actions were taken into considerations when survey was developed and disseminated.

The results confirm that main employers of IS graduates are international companies. Also customers of IT projects the graduates work for are mostly international. As most respondents are based in Romania, these findings support the statement that Romanian IT industry is massively based on outsourcing.

Other findings contradict some statements found in the mainstream IS literature and/or our suppositions. Female graduates are more numerous than males (which does not conform to the much debated scarcity of women in computing). Also female graduates target technical jobs similarly to their gender counterparts (which contradicts the idea that males are more technically oriented). In our sample, there is no trace of sexual/genre discrimination in getting IT managerial positions. Also the managerial positions seem to be equally accessible to all graduates, no matter the graduation year.

The results also suggest a proper alignment of IS programme to the industry needs and a very satisfactory graduates employability. We also found out that most of graduates' professional careers were related to software development, especially the final stages of software development, and that the technical skills were required more than businessoriented ones. These finding might explain why the courses issue had a negative contribution on programme reputation compared with the teaching stuff issue. Unlike Western IS programmes Romanian ones must cope with technical skills, i.e. programming, databases, computer networks, etc.

Obviously, the current state of IT workforce market is hugely induced by the globalization and its size is increasing at a very fast pace. But a question is arising: Will the Romanian market maintain the same structure of IT occupation or it will change? If it changes, can we predict the future trends? Certainly, it is not easy to get answers to these questions forasmuch the globalization of software and its manifestation as IT services off shoring is a disruptive force that has a long-term effect on the domestic IT services market. The literature failed to offer a clear response on this subject for at least two reasons.

Firstly, there is no coherence about what IT work could be off shored. At first it was believed that the only software jobs that would be off shored were low-level jobs, such as routine software maintenance and testing, programming, and call centres. Some authors try to prove that the vulnerability of IT jobs/skills depends on their features. Thus, the jobs and skills that need physical presence of workers in a fixed location and interpersonal interaction and face-to-face contact with developed country-based customers are less readily to be off shored [13], [32]. Also, the IT skills which are seen as critical to achieving the mission of a firm in the sense that those skills lead to a competitive advantage should be retained in-house [14]. Today, many people believe that any kind of 
IT job/skill can be off shored. Carr states that all IT is destined to become commoditybased from cost savings and management perspectives, the main reason being that IT services do not provide a competitive advantage [11]. Fulbright and Rough claim that in time some IT skills tend to become new commodity [12]. Even if it is possible to offshore all type of IT work, it does not mean that all jobs actually will be offshore. In fact, there are a number of reasons why a company might not wish to offshore work: the off shoring impacts too negatively on the client firm such as the client firm losing control over an important work element; risks to privacy, data security, or intellectual property are too high; there are cultural issues that stand between the client and IT service provider [15].

Secondly, data on current and future trends of off shoring presented in different studies is not trustworthy. The definitions of off shoring vary from one study to another, making it hard to compare statistics, the metric used in measuring the extent and trends in off shoring is different from one study to another [15].

To conclude, there are many challenges in implementing an educational response to globalization of IT services that the higher education system to act proactively. IT work encompasses many different occupations, each with its own skill and knowledge requirements and it is difficult to find out early what skills and knowledge to offer to students. That means the educational systems will have to continually adapt to changes induced by the globalization.

There are some limitations of this study. The number of respondents is satisfactory, but one can ask if the graduates who filled in the questionnaire faithfully represent the entire population of BIS graduates. It is possible that unlucky or ill-prepared graduates who have not succeeded in getting a rewarding job avoided answering. Also the distance between survey and graduation time could affect the quality of some answers.

In the next stage of our study we will check the hypothesis of increasing the weight of technical courses in the master programme curricula to the injury of business-oriented subjects. We will also try to find out the details about the technology required by Romanian IT industry and the future trends of IT skills from the industry perspective.

\section{Acknowledgment}

The $\mathrm{R}$ solution for master analysis was developed within ASIGMA (Asigurarea Calității în Învățământul Masteral Internaționalizat: Dezvoltarea cadrului național în vederea compatibilizării cu Spaţiul European al Învățământului Superior) project, POSDRU/86/1.2/S/59367

\section{References}

[1] I. Benbasat and R. Zmud, "The Identity Crisis Within the IS Discipline: Defining and Communicating the Discipline's Core Properties," MIS Quarterly, vol. 27, no. 2, pp. 183-194, 2003.

[2] R. Hirschheim and H. Klein, "Crisis in the IS Field? A Critical Reflection on the Status of the Discipline," Journal of the Association for Information Systems, vol. 4, no. 5, pp. 237-293, 2003.

[3] M. Fotache, "Information Systems / Business Informatics Programmes in Europe. Uniformity or Diversification?," in Proc. of the Second Symposium on Business Informatics in Central and Eastern Europe - CEE Symposium 2011, ClujNapoca, Romania, 2011.

[4] J. Downey, R. McGaughey and D. Roach, "Attitudes and Influences toward Choosing a Business Major: The Case of Information Systems," Journal of Information Technology Education, vol. 10, no. 1, pp. 231-251, 2011.

[5] D. Frankel, "Danger: MIS Schools in Decline," 9 2008. [Online]. Available: www.bptrends.com.

[6] C. Barnes and K. Bandyopadhyay, "A successful curriculum strategy to increase MIS enrollment," in Proceedings of the Southwestern DSI, 2012.

[7] M. Helfert and H. Duncan, "Evaluating information systems and business informatics curriculum," in CompSysTech'07 
- Proceedings of the 2007 international conference on Computer systems and technologies, 2007.

[8] Eurofound, "ERM report 2012 - After restructuring: Labour markets, working conditions and life satisfaction," 2012. [Online]. Available: http://www.eurofound.europa.eu/sites/def ault/files/ef_files/pubdocs/2012/61/en/1/ EF1261EN.pdf. [Accessed 1504 2015].

[9] S. Văduva, A. Giurca, I. Fotea and P. Filip, "The Economic Impact of Doubling the Number of Employees in the Romanian IT Sector," in Proceedings Of The 8th International Management Conference "Management Challenges For Sustainable Development, Bucharest, Romania, 2014.

[10] A. Grama and V. Păvăloaia, "Outsourcing IT - The Alternative for a Successful Romanian SME," Procedia Economics and Finance, vol. 15, pp. 14041412, 2014.

[11] N. Carr, "IT doesn't matter," Educause Review, vol. 38, pp. 24-38, 2003.

[12] R. Fulbright and R. Routh, "How information technology professionals keep from being outsourced or offshored," in Proceedings of the 5th conference on Information technology education, Association for Computing Machinery, 2004.

[13] P. Tambe and L. Hitt, "How offshoring affects IT workers," Communications of the ACM, vol. 53, no. 10, pp. 63-70, 2010

[14] P. Zwieg, K. Kaiser, C. Beath, C. Bullen, K. Gallagher and T. Goles, "The information technology workforce: Trends and implications 2005-2008," MIS Quarterly Executive, vol. 5, no. 2, p. 47-54, 2006.

[15] W. Aspray, F. Mayadas and M. Vardi, "Globalization and Offshoring of Software - A Report of the ACM Job Migration Task Force," Association for Computing Machinery , 2006.

[16] H. Topi, J. S. Valacich, R. T. Wright, K. Kaiser, J. F. Nunamaker Jr, J. C. Sipior and G. J. de Vreede, "IS 2010: Curriculum guidelines for undergraduate de- gree programs in information systems," Communications of the Association for Information Systems, vol. 26, no. 1, p. $18,2010$.

[17] J. T. Gorgone, P. Gray, E. A. Stohr, J. S. Valacich and R. T. Wigand, "MSIS 2006: model curriculum and guidelines for graduate degree programs in information systems," ACM SIGCSE Bulletin, vol. 38, no. 2, pp. 121-196, 2006.

[18] B. Muenchen, "Job Trends in the Analytics Market: New, Improved, now Fortified with C, Java, MATLAB, Python, Julia and Many More!," 25022014. [Online]. Available: http://r4stats.com/2014/02/25/job-trendsimproved/. [Accessed 0503 2015].

[19] M. Fotache, "Using R for Data Analysis of Master Graduates Survey," in Proc. of the 23rd International Business Information Management Conference (IBIMA), Valencia, Spain, 2014.

[20] D. Meyer, A. Zeileis and K. Hornik, "vcd: Visualizing Categorical Data. R package version 1.4-1.," 08072015. [Online]. Available: https://cran.rproject.org/web/packages/vcd/.

[21] H. Wickham, "stringr: modern, consistent string processing," 122010. [Online]. Available: http://journal.rproject.org/archive/2010-

2/RJournal 2010-2 Wickham.pdf.

[22] G. Sanchez, "Handling and Processing Strings in R," 2013. [Online]. Available:

http://gastonsanchez.com/Handling_and_ Processing_Strings_in_R.pdf. [Accessed 0102 2015].

[23] H. Wickham, "Reshaping data with the reshape package," Journal of Statistical Software, vol. 21, no. 12, pp. 1-20, 2007.

[24] H. Wickham, "The Split-ApplyCombine Strategy for Data Analysis," Journal of Statistical Software, vol. 40, no. 1, pp. 1-29, 2011.

[25] H. Wickham, ggplot2: Elegant Graphics for Data Analysis, New York: Springer, 2009.

[26] J. Bryer and K. Speerschneider, "lik- 
ert: Functions to analyze and visualize likert type items. R package version 1.2," 2014. [Online]. Available: http://CRAN.Rproject.org/package=likert. [Accessed 01 02 2015].

[27] C. V. Bullen, T. Abraham, K. Gallagher, J. C. Simon and P. Zwieg, "IT Workforce Trends: Implications for Curriculum and Hiring," Communications of the Association for Information Systems, vol. 24, no. 1, p. 9, 2009.

[28] R. Hirschheim, C. Loebbecke, M. Newman and J. Valor, "Offshoring and its implications for the information systems discipline: Where perception meets reality," Communications of the Association for Information Systems, vol. 20, no. 1, p. 51, 2007.

[29] W. Gray and T. Connolly, "The impact of off shoring on the evolution of the IT workforce within the UK," Interna- tional Journal of Information Technology and Management (IJITM), vol. 7, no. 4, pp. 356-373, 2008.

[30] D. Yen, K. Chen, S. Koh and S. Lee, "An East-West Comparison of IS Professionals' Performance and Knowledge/Skills: An Empirical Study of USA vs Taiwan," Communications of the Association for Information Systems, vol. 15, no. 1, p. 9, 2005.

[31] P. Szlęzak, "IT profiles in request of outsourcing and final customers," Polish Journal of Management Studies, vol. 9, pp. 225-232, 2014.

[32] L. Hurbean and D. Fotache, "ERP III: The Promise of a New Generation," in Conference on Informatics in Economy ASE Bucarest Romania 2014, Bucharest, Romania, 2014.

[33] A. S. Blinder, "How many US jobs might be offshorable?," World Economics, vol. 10, no. 2, p. 41, 2009.

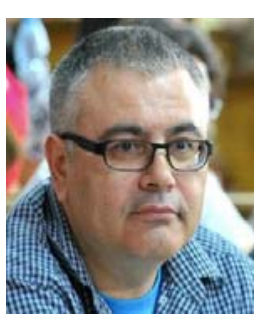

Marin FOTACHE graduated (long time ago) the Faculty of Economics at Alexandru Ioan Cuza University of Iasi, Romania. He holds a PhD diploma in Business Information Systems (Business Informatics) from 2000. He had gone through all teaching positions since 1990 when he joined the staff of Alexandru Ioan Cuza University, from teaching assistant in 1990, to full professor in 2002. Currently he is professor within the Department of Accounting, Business Informatics and Statistics in the Faculty of Economics and Business Administration at Alexandru Ioan Cuza University. He is the (co)author of books and journal articles in the fields of SQL, database design, NoSQL, Big Data, and knowledge management.

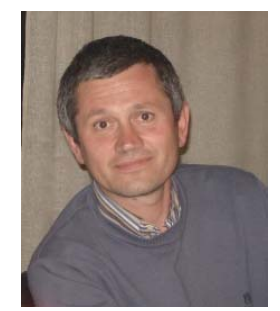

Florin DUMITRIU graduated the Faculty of Economics at Alexandru Ioan Cuza University of Iasi, Romania in 1991. He holds a PhD diploma in Accounting (Accounting Information Systems) from 2001 and he had gone through all teaching positions since 1995 when he joined the staff of Alexandru Ioan Cuza University, from teaching assistant in 1995, to full professor in 2007. Currently he is professor within the Department of Accounting, Business Informatics and Statistics in the Faculty of Economics and Business Administration at Alexandru Ioan Cuza University. He is the (co)author of books and journal articles in the fields of Software Analysis and Design, Global Software Development, Agile Methodology, and Accounting Information Systems. 


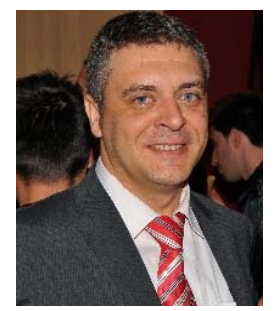

Valerică GREAVU-ȘERBAN graduated the Faculty of Economics and Business Administration in 1998. He holds a PhD diploma in Cybernetics from 1999. In 2006 he joined the staff of the Alexandru Ioan Cuza University of Iași first as teaching assistant and then as lecturer professor (since 2009). He is the (co)author of books and journal articles in the fields of IT security, computer networks, portal platforms, education, e-commerce, and cloud computing. 